\title{
'WE FEEL STUPID AND WE SHOULDN'T.' TOWARDS DEVELOPING A COMMUNICATION SUPPORT SYSTEM FOR CUBAN-TRAINED MEDICAL STUDENTS
}

\author{
Jessica Gasiorek \\ University of Hawai'i at Manoa \\ Kris Van de Poel \\ University of Antwerp
}

-How do you cope? All of you are smiling and nodding.
How do you cope?
-It is really hard.

-Well, in my opinion, I think, well for me to survive.

I didn't quit in Cuba, so you don't quit here.

-You don't quit anywhere.

This article presents a case study of a small group of South African medical students who have returned to South Africa after six years of medical education in Cuba, where they were trained in a different language (Spanish) and medical system (Cuban) from what they will ultimately practice in as South African doctors. This study sought to better understand the linguistic, cultural, and communicative challenges that this group faced upon returning to South Africa, with the ultimate goal of creating materials to support the students' language learning in the clinical domain. The researchers found that students reported considerable difficulties with (re-)integrating into South African culture and clinical contexts; specific issues included encountering different types of medical issues in South Africa compared to Cuba and difficulty in understanding and using medical terminology in English and Afrikaans. This case study concludes with specific recommendations for developing learning materials that address these students' unique linguistic and communicative needs.

\section{BACKGROUND}

\subsection{HEALTH COOPERATION AGREEMENT: CUBA AND SOUTH AFRICA}

In 1995, South Africa and Cuba signed a Health Cooperation Agreement (South African Government online) as part of an intervention seeking to address the shortage of qualified medical doctors in South Africa (Health Care in South Africa). Through this programme, students from South Africa spend the first six years of their medical training in Cuba. Their training period consists of twelve months of Spanish language training in Cuba, followed by five years of medical training undertaken in Spanish. After six years of training in Cuba, the students then return to South Africa to complete their medical education. This Cooperation Agreement was designed in such a way that the students are exposed to the health care and 
medical education systems of both countries. As such, they benefit from the advantages of the different training models addressing primary health care (prevention-focused as in Cuba) as well as curative care (disease-focused as in South Africa).

South Africa provides eighty scholarships per annum for medical students to be trained in Cuba, but this number will increase from 2013 onwards (Business Day 2012). This number is evenly distributed amongst the participating provinces. The agreement specifically targets candidates from disadvantaged backgrounds (SA News 2013).

Upon returning to South Africa after their six years in Cuba, students from this programme complete their training at a South African university. At Stellenbosch University, ${ }^{1}$ where participants in this study were enrolled, this comprises a four-month orientation programme. During the programme, students receive additional medical skills training, take language courses in English and Afrikaans, and do supervised clinical ward rotations in the local university hospital. After this orientation programme, and a total of 7.5 years of medical training, students write the Cuban medical examination and are awarded a Cuban degree accredited by Stellenbosch University. They then spend a year's residency (internship) at another site in South Africa. Finally, they complete their medical training with a year of community service, which is typically undertaken at understaffed hospitals and clinics, often in a rural or underserved community.

In what follows, we present a case study of a small group of South African medical students (eight so-called black South Africans and two coloured South Africans) who have returned to South Africa after six years of medical education in Cuba. The goal of this study was to investigate the unique linguistic, cultural, and communicative challenges that these students faced upon re-entry as they studied and worked in the training hospitals. On the basis of the study's findings, we make recommendations for the development of a teaching programme and materials (the responsibility of the university's Language Centre) to support and improve these students' medical communication skills in English and Afrikaans. The research presented here was part of the Language Centre's involvement in a larger international project addressing medical communication skills (Medics on the Move; www.comforpro.com). It was conducted with the consent of the Faculty of Medicine and Health Sciences, whose staff members participated as consultants in the setup of the study. Ethical clearance for this project was granted, as it related to informed decision making with regard to assessment and course design, and adhered to normal ethical practices. ${ }^{2}$

\subsection{MEDICAL COMMUNICATION}

Communication skills play a central role in patient-oriented medicine, as the quality of communication between doctors and their patients, and between doctors and fellow healthcare professionals, influences the quality of patient care (e.g., Watson, Hewett \& Gallois, 2012;

\footnotetext{
${ }^{1}$ We are grateful to the Faculty of Medicine and Health Sciences, Stellenbosch University and the Tobie van Dyk and Suzanne Ross from the Unit for Afrikaans and English at Stellenbosch University's Language Centre. We also wish to express our gratitude and admiration for the students who took part in this needs analysis pilot.

2 Students recruited for participation were all students taking part in the university's Afrikaans course. All participation was voluntary, and no one was disadvantaged by (not) taking part. There was informed consent and there was no penalty for withdrawing from the study. Students commented that they regarded this to be a useful and important project to which they wanted to contribute.
} 
Hewett et al., 2009). Most internationally accepted foundational works on medical communication (e.g., Bickley \& Szilagiy, 2007; Pendleton et al., 2007; Prabhu \& Bickley, 2007; Silverman, Kurtz \& Draper, 2006; Tate, 2007) focus primarily on how to carry out clinical consultations, and assume a monolingual communication context. Multilingual contexts or language-discordant encounters are typically mentioned as a potential challenge, but only referred to in passing. To date, most research on language-discordant medical communication has focused on language-discordant patients who communicate with or without the help of cultural mediators (e.g., Ferguson \& Candib, 2002; Hornberger et al., 1996; Hudelson, 2005; Pöchhacker \& Shlesinger, 2005; Rudvin \& Tomassini, 2008; Schouten $\&$ Meeuwesen, 2006). However, the linguistic and communicative needs of languagediscordant medical professionals have recently been receiving an increasing amount of academic attention (for an overview of the international literature, see, e.g., Van de Poel \& Brunfaut, 2010; Gasiorek \& Van de Poel, 2012; Van de Poel et al., 2013; and for a South African perspective, see Van de Poel \& Fourie, 2013).

In a South African context, multilingualism is a critical issue in medical practice: generally, to practise medicine effectively, doctors need to be functional in one or more local languages (e.g., isiXhosa, isiZulu, Sepedi, etc.) in addition to English and, sometimes, Afrikaans. Medical students who have been trained in Cuba and return to South Africa to complete their medical degree have undertaken all of their medical training in Spanish. As such, the majority of their medical vocabulary, as well as more general knowledge of medical communication practices, is in Spanish. To be able to communicate and practise medicine effectively in South Africa, they need to re-learn nearly all their medical vocabulary, terminology, and related interactional scripts.

\section{LANGUAGE TRAINING AT STELLENBOSCH UNIVERSITY}

Returning students (referred to as $S A$ Cuban-trained students in official documents and the media) completing medical studies at Stellenbosch University are given 22 hours of Afrikaans instruction and 28 hours of English instruction as part of their (re-)orientation programme. For the past seven years, the Afrikaans course has taken a general and contextualised medical approach to language teaching, using interactive activities such as role-play and games (Total Physical Response) to teach content such as names for body parts, diseases, instruments, numbers (contextualised as weight and readings like blood pressure, sugar level, urine tests, etc.), colour and clothing, and doctor-patient communication in various scenarios. The English classes focus more on academic reading and writing skills but also include professional patient-doctor communication in various scenarios (personal communication $\mathrm{S}$. Ross).

Given that the hours available for contact teaching during the re-entry period are minimal, Stellenbosch University's Unit for Afrikaans wanted to study the potential of increasing learning output for these students. To this end, we conducted a case study of a small group of these students with the aim of identifying the unique linguistic, cultural, and communicative challenges these students faced upon re-entry. On the basis of these students' self-reported experiences and pedagogical needs (part of a systematic needs analysis; see Van de Poel, 2011 and Van de Poel \& Fourie, 2013), we offer specific recommendations for the 
development of language training materials for this unique population (i.e. language programme design following Brown, 1995; Nation \& Macalister, 2009).

\section{METHOD}

\subsection{PARTICIPANTS}

Ten students ( $n=5$ male and $n=5$ female) took part in this study on a voluntary basis. To participate in the study, students had to have participated in the Cuban-SA program recently (2011 or 2012). Students who took part in the study all participated in the Afrikaans course at Stellenbosch University. Six of these participants had just completed the orientation programme (in 2012); the other four had completed it the previous year (2011). Participants were between 25 and 29 years old; two were so-called coloured South Africans, the others were so-called black South Africans. Members of the group self-identified as speakers of a number of different languages: English, Spanish, Sepedi, Afrikaans and Tshivenda, isiXhosa, isiZulu, Setswana and Sesotho. All participants anticipated primarily using English in their future medical practice, but some also expected to use Sepedi or other local African languages. All written data collected were anonymous, and it was agreed that all data (written and focus group responses (see below)) would be treated confidentially.

\subsection{MATERIALS AND PROCEDURE}

The needs analysis consisted of a paper questionnaire and a follow-up focus group discussion, both primarily in English, focusing on students' experiences (a) returning to South Africa after six years of training in Cuba and (b) communicating in a clinical setting (see Appendix 1). The questionnaire and focus group discussion were completed in a single session with the first author, in the presence of the director of the Unit for Afrikaans and English at Stellenbosch University, as well as the students' Afrikaans instructor. Introductions were done in Afrikaans and English. Students completed the questionnaire (self-administered, although they were given the opportunity to ask any questions they had about its content) in less than 30 minutes.

The questionnaire included items asking students what they found most challenging since returning to South Africa in general, in terms of language, in their medical training, and in daily life, as well as what differed between their medical training in South Africa compared to that in Cuba (open-ended). To investigate their identification and self-perceptions following their time abroad, students were also asked to complete a series of visual measures. These consisted of pairs of increasingly overlapping circles representing themselves and the target groups, modelled after Schubert \& Otten, 2002. and were intended to measure their perceptions of the relationships between Cuban and South African people, Cuban and South African doctors, and doctors trained in Cuba and in South Africa; and how they viewed themselves relative to Cubans, South Africans, Cuban doctors, South African doctors trained in Cuba, South African doctors trained in South Africa, English-speakers, Spanish-speakers, and Afrikaans-speakers. No explicit definitions of these categories were provided; students responded on the basis of their experience as individuals who have lived in both South Africa and Cuba. 
To better understand students' contextualised language use and needs, the questionnaire also asked students to indicate how often they spoke different languages (Spanish, English, Afrikaans, isiZulu, isiXhosa, or another language specified by the participant) with (1) other students trained in Cuba, (2) South African-trained medical students, and (3) their supervisors, as well as how confident they felt speaking each of these languages with each of these target groups (closed-ended, five-point Likert-type scale). They were also asked what languages they would like additional training in, and what areas or topics they would like this training to address.

In the focus group discussion, students were asked about their experiences on returning to South Africa after their years of training abroad, the issues they encountered in their academic, professional, and personal lives, and how they were coping with them.

To investigate students' language use and self-perceptions, means for each of the corresponding questionnaire items were calculated and examined. Because of the small sample size, it was not possible to formally compare item response means using traditional inferential statistics (e.g., paired sample $t$-tests).

To investigate the specific issues that students experienced in medical and clinical settings, as well as broader issues related to re-entry, open-ended data from the questionnaire and transcripts of the focus group discussion were analysed qualitatively.

\section{RESULTS AND DISCUSSION}

\subsection{LANGUAGE USE AND IDENTIFICATION}

After their time abroad, these students exhibited a sort of dual identity: while they still identified strongly with South Africans $(M=5.30, S D=1.17$, on a seven-point scale), they also identified strongly with Cubans $(M=5.90, S D=1.45)$, and with Cuban doctors $(M=$ $5.70, S D=1.49)$. In terms of language, they identified most strongly as Spanish speakers $(M$ $=5.10, S D=1.85)$, and only moderately as English speakers $(M=4.50, S D=1.65)$ and Afrikaans speakers $(M=3.40, S D=2.17)$. They perceived a fair amount of distance between Cubans and South Africans (distance $M=2.60, S D=1.78$, on a seven-point scale), doctors trained in Cuba and those trained in South Africa $(M=2.90, S D=2.18)$, and Cuban doctors and South African doctors $(M=1.70, S D=1.06)$.

Among themselves, this group of students reported speaking primarily English and Spanish, and doing so with similar frequency $(M=3.90, S D=0.57$ and $M=3.70, S D=1.06$, respectively, on a five-point scale) and high levels of comfort with both languages $(M=5.00$, $S D=0$ and $M=4.80, S D=0.42$, respectively). With other South African-trained medical students and their supervisors, they reported speaking primarily English $(M=4.50, S D=0.97$ and $M=4.80, S D=0.57$ for each target group, respectively).

\subsection{COMMUNICATING IN MEDICAL AND CLINICAL SETTINGS}

In both the interview and the follow-up focus group discussion, students commented on the difficulty of the linguistic transition from Spanish to English and/or Afrikaans that 
accompanied their return to South Africa. Having to move from Spanish to English or Afrikaans, particularly with respect to medical terminology, was cited as one of the most challenging things they had to deal with in their medical training. Students expressed their frustration with knowing the content in question, but being unable to communicate that fact. As one student articulated, 'It is not that we don't know. We know, but we cannot express ourselves' (S1).

Having the relevant medical and clinical knowledge but not the vocabulary to effectively express it puts these students in a difficult position in their professional interactions. As one student recounted, 'You find yourself in a ward and almost everything that you see you don't know what it is, so you have to keep asking every second word. They look at the nametag and you're supposed to be a student intern' (S3). Students commented particularly on the use of abbreviations, which one student referred to as 'a secret code' (S4) (cf. the medical jargon literature; for an interesting example see Levin (2006), showing how different uses of medical terminology affect doctor-patient communication in a South African paediatric teaching hospital).

Students reported that responses to their lack of vocabulary varied; some members of the hospital staff were helpful, others responded more negatively. However, students emphasised that 'even with those who are willing you cannot ask everything every second' (S1). As perceptions of linguistic competence are coupled with perceptions of professional competence (e.g., Gasiorek \& Van de Poel, 2012) students likely feel that asking too many questionsespecially those that could be perceived as very basic - could hurt their credibility as medical professionals.

Lacking the language skills that both they and their colleagues thought they 'should' have, these students felt at risk of losing face professionally. Having such experiences made them feel 'stupid'. As several students articulated, '[T]hey keep encouraging you to feel confident and all that, but, really, how can you be?' (S5) 'Honestly, they ask you a question and they look at you in a funny way.' (S7) "'How did you get here?" is the first question.' (S3) In short, as one student put it: 'We feel stupid and we shouldn't' (S1).

To cope with these difficulties, students said they asked other South African students (a few of whom 'are very accommodative' (S8)), and make their own notes and vocabulary lists. These students expressed that this transition was very difficult for them, but that they were committed to getting through it: 'I didn't quit in Cuba so you don't quit here' (S3). 'You don't quit anywhere.' (S1)

The difficulties with terminology were compounded by differences in medical equipment and medical practices between Cuba and South Africa. Students reported that, not only the names for medical equipment in South Africa are different, but the equipment itself is different. The types of medical issues they face are also different: training in South Africa is more hands-on (i.e., students perform more medical procedures); the general approach to medicine is more curative than preventative, which is as it is in Cuba. The burden of disease differs considerably between the two nations. With such difference, students struggle psychologically with 'coming back from the hospital and feeling like I don't know anything' (S6) and 'the integration of what I learnt in Cuba in a South African system, given that all I learnt seems as if it was a joke' (S1). 


\subsection{RE-ENTRY}

In addition to these issues in their professional endeavours, students also reported difficulties (re-)integrating into South Africa in their personal lives. Several students indicated that they had trouble 'relating to South Africans again' (S3) and 'integrating back into society' (S5). They commented that the food was different, and that popular language (jargon, slang) had changed, making it difficult to understand their peers or members of younger generations. In the time they were away, friends had also moved away or moved on. Students found these changes troubling: 'I feel like a stranger in my own country,' (S4) said one. The most challenging part of returning, another said, was 'to fit in the family again [...] sometimes you feel like a visitor in your own house' (S1).

These experiences are broadly consistent with those reported in the literature on re-entry (for a recent review, see Szkudlarek, 2009). Although most research in this area is on corporate repatriates, a number of studies have also addressed students' experiences. Psychological discomfort and/or distress has been widely documented among returning sojourners in general, and students in particular (Szkudlarek, 2009). These difficulties have been found to stem both from changes that have occurred in the individuals who have spent time abroad and in the home environment while individuals have been away. This is consistent with these students' experiences: as one put it, 'I feel alone because I don't have friends here in South Africa anymore because people have moved on with their lives and we have different views and opinions now' (S7). Elements of their home environment have changed, but so have they.

Because of their age and life-stage, students often experience more profound changes in their personal identity as a result of time spent abroad than do older individuals. As such, they may have greater difficulty readjusting to their home-country environment when they return, and/or be less willing to give up new aspects of their identity. As one student put it, 'I grew up in Cuba. Everything I know I learned there' (S3). Although we have limited data from the focus group specifically addressing this issue, it is clear that, even several months (or, in some cases, more than a year) after returning, these students identify strongly with Cubans, Cuban doctors, and Spanish speakers.

\section{RECOMMENDATIONS FOR MATERIALS DEVELOPMENT}

Despite the limitations inherent in this study — most notably, the small sample size and single site for data collection - we can make some preliminary recommendations for developing language learning and support materials on the basis of its findings.

To address their lack of vocabulary and, more specifically, terminology, students have to be systematically presented with words for utensils as used in medical procedures. This would help familiarise students with both local medical equipment (as this was identified as an important difference between Cuban and South African hospital environments), and with local names for it (e.g., ' $n$ verkie for a type of tube with a thick needle (S1)), which students currently experience as 'secret codes' (S2). To bridge the linguistic gap between Spanishwhere the bulk of students' medical vocabulary is - and English, illustrated multilingual word lists containing Spanish and reflecting the contexts the students encounter could be helpful. 
To effectively foster contextualised learning, the words and terms should be grouped by topic (semantic fields) (Van de Poel \& Swanepoel, 2003).

Students' overarching complaints about their lack of communicative competence ('It is not that we don't know; we know, but we cannot express ourselves' (S1) or 'They ask you something you do know it in Spanish, but you cannot express it' (S6)) require a contextualised approach to language and communication. Annotated medical scenarios that highlight key intercultural differences could provide students with concrete communication strategies, with related phrases or terminology. The scenarios should integrate reference to medical equipment and procedures, as well as interaction scripts, and could follow the consultation timeline as a frame of reference. Here again, having English and Afrikaans texts with Spanish counterparts (with key cultural differences highlighted) may also be helpful. Conventional scripts can be used by the students to study how to initiate a session, gather information (case histories), perform physical examinations, explain and plan and close the session. Scripts can also take the form of interactive scenarios in which one interactant takes on the role of the patient presenting with a particular disease (e.g., Kwong et al., 2009). Having these scripts as resources can help students both prepare for their exams and practise standard procedures such as the OSCE (the Objective Structured/Standardised Clinical Examination or OSCE). However, the educational value of scripts as checklists in a communication learning environment has to be approached with caution (see Skelton, 2008 for a critical approach). In a language-discordant context they definitely should be reinforced by additional training in communication skills (see, among others, Moss and Roberts, 2003; Roberts et al., 2008).

Such guides should ideally be developed by a team of researchers, communication specialists, language teachers, and skills laboratory staff, and developed specifically for a multilingual and multicultural South African context. These support tools should also comply with the syllabus (goals and objectives) approved by the teaching and learning committees of the relevant university (in this case, Stellenbosch University). If these communication support tools are developed as online/mobile resources, they have the potential to foster the learners' autonomous and continuous learning and training in a clinical context, which could provide benefits well beyond the students' initial return and orientation programme (see Van de Poel \& Fourie, 2013).

Although this study focused primarily on language and communication issues experienced by these students, participants' responses also indicated that students more generally faced considerable social and psychological challenges with respect to the re-entry process. Students notably still felt a strong sense of connection to Cuban and Spanish-speaker identities. While we are not suggesting that students be asked to abandon or divest themselves of these identities, it is important for their South African supervisors and colleagues to be aware of students' self-perceptions, as well as the potential stress they may be experiencing. We also suggest that supervisors and hospital staff be explicitly encouraged to show patience and understanding for the situation that these students are experiencing. To the extent possible, orientation programmes (such as the one studied here) should consider including elements that specifically address issues and challenges related to returning to South Africa after six years abroad and/or re-entry and (reverse) culture shock more generally. 


\section{CONCLUSION}

This article presented a case study of a small group of South African medical students who have returned to South Africa after six years of medical education in Cuba, where they were trained in a language (Spanish) and medical system (Cuban) different from that they will ultimately practise in as South African doctors. On the basis of its findings about the linguistic, cultural, and psychological challenges this group faced upon returning to South Africa, we offered preliminary recommendations for developing a set of materials to support these students' language learning in context. In so doing, we also hope to raise awareness of these students' unique linguistic and cultural situation. We fully recognise that language support materials are far from a 'cure-all' for the complex social, psychological and communicative situations in which these students are. We hope, however, that it may be a resource to help students save mental energy (i.e., by removing the burden of constructing language learning materials on their own), which should give them more available mental resources to cope with other challenges of re-entry, and to engage more fully in other areas of their pre-professional life.

\section{REFERENCES}

BICKLEY, LS \& PG SZILAGIY. 2007. Bates' guide to physical examination and history taking. Philadelphia: Lippincott Williams \& Wilkins.

BROWN, JD. 1995. The elements of language curriculum: A systematic approach to program development. Boston, MA: Heinle \& Heinle.

BUSINESS DAY. 2012. SA signs deal with Cuba for more doctors (28 May 2012). http://www.bdlive.co.za/articles/2012/05/28/sa-signs-deal-with-cuba-for-moredoctors;jsessionid=8AE18B3EAA610E08F0D3AE90188CCB15.present1.bdfm [2014, February].

FERGUSON, WJ \& LM CANDIB. 2002. Culture, language, and the doctor-patient relationship. Fam Med, 34(5):353-361.

GASIOREK, J \& K VAN DE POEL. 2012. Divergent perspectives on language-discordant mobile medical professionals' communication with colleagues: An exploratory study. Journal of Applied Communication Research, 40-4:368-383.

HEALTH CARE IN SOUTH AFRICA. South Africa.info website. http://www.southafrica.info/about/health/health.htm\#.Ubzac-tWwk9 [2013, June 15].

HEWETT, DG, BM WATSON, C GALLOIS, M WARD \& BA LEGGETT. 2009. Communication in medical records: intergroup language and patient care. Journal of Language and Social Psychology, 28:119-138.

HORNBERGER, JC, CD GIBSON, W WOOD, C DEQUELDRE, I CORSO, B PALLA \& DA BLOCH. 1996. Eliminating language barriers for non-English-speaking patients. Med Care, 34(8):845-856.

HUDELSON, P. 2005. Improving patient-provider communication: insights from interpreters. Fam Practice, 22(3):311-316. 
KWONG, TY, Q KWONG, A O'BRIEN, J HASWELL \& K HILL. 2009. Medical communication skills and law: The patient-centred approach made easy. Edinburgh: Churchill Livingstone Elsevier.

LEVIN, ME. 2006. Different use of medical terminology and culture-specific models of disease affecting communication between Xhosa-speaking patients and Englishspeaking doctors at a South African paediatric teaching hospital. $S$ Afr Med J., Oct 96(10):1080-4.

MOSS, B \& C ROBERTS. 2003. Doing the Lambeth talk: Real-life GP-patient encounters in the multi-lingual city. London: Kings College/London Deanery.

NATION, ISP \& J MACALISTER. 2009. Language curriculum design. New York/Abingdon: Routledge.

OSCE - THE OBJECTIVE STRUCTURED/STANDARDISED CLINICAL EXAMINATION [Online]. www. oscehome.com [2014, February].

PENDLETON, D, T SCHOFIELD, P TATE \& P HAVELOCK. 2007. The new consultation: developing doctor-patient communication. Oxford: Oxford University Press.

PÖCHHACKER, F \& P SHLESINGER. 2005. Discourse-based research on healthcare interpreting. Interpreting, 7(2):157-165.

PRABHU, FR \& SL BICKLEY. 2007. Case studies to accompany Bates' guide to physical examination and history taking. Philadelphia: Lippincott Williams \& Wilkins.

ROBERTS, C, C ATWELL, T SWANWICK \& N CHANA. 2008. Words in action: Communication skills for doctors new to UK general practice. London: Kings College/London Deanery.

RUDVIN, M \& E TOMASSINI. 2008. Migration, ideology and the interpreter-mediator. The role of the language mediator in educational and medical settings in Italy. In Garcés CV \& A Martin (Eds), Crossing borders in community interpreting: definitions and dilemmas. John Benjamins, Amsterdam. 245-266.

SA NEWS. SOUTH AFRICAN GOVERNMENT NEWS AGENCY. 2013/25/09. 'NW Youth to study medicine in Cuba' [Online]. http://www.sanews.gov.za/south-africa/nwyouth-study-medicine-cuba [2014, February].

SCHOUTEN, BC \& L MEEUWESEN. 2006. Cultural differences in medical communication: a review of the literature. Patient Educ Couns, 64 (1-3):21-34.

SCHUBERT, T \& S OTTEN. 2002. Overlap of the self, ingroup, and outgroup: Pictoral measures of self-categorization. Self and Identity, 1:353-376.

SKELTON, J. 2008 Language and clinical communication: this bright Babylon. Oxford and New York: Radcliffe.

SILVERMAN, JD, SM KURTZ \& J DRAPER. 2006. Skills for communicating with patients. Oxford/San Francisco: Radcliffe.

SOUTH AFRICAN GOVERNMENT ONLINE. http://www.gov.za/aboutsa/international_relations.htm and http://www.gov.za/speeches/2008/08052710451007.htm [2013, June].

SZKUDLAREK, B. 2009. Reentry-a review of the literature. International Journal of Intercultural Relations, 34:1-21. 
TATE, P. 2007. The doctor's communication handbook. Oxford: Radcliffe.

VAN DE POEL, K. 2011. From multidimensional needs to language training for mobile professionals: an interdisciplinary approach. In De Wannemacker, S, G Clarebout \& P de Causmaecker (Eds), Communications in information and computer science, pp. 7084. Berlin/Heidelberg: Springer Verlag.

VAN DE POEL, K \& T BRUNFAUT. 2010. Medical communication in L1 and L2 contexts: Comparative modification analysis. Intercultural Pragmatics, 7-1:103-129.

VAN DE POEL, K \& C FOURIE. 2013. A critical approach to the development of blended medical communication training materials. Stellenbosch Papers in Linguistics Plus, 42:333-351.

VAN DE POEL, K \& P SWANEPOEL. 2003. Theoretical and Methodological Pluralism in Designing Effective Lexical Support for CALL. CALL, 16-2/3:173-211.

VAN DE POEL, K, E VANAGT, U SCHRIMPF \& J GASIOREK. 2013. Communication Skills for Foreign and Mobile Medical Professionals. Berlin/Heidelberg: Springer.

WATSON, BM, DG HEWETT \& C GALLOIS. 2012. Intergroup communication and health care. In Giles H (Ed), The handbook of intergroup communication, pp. 293-305. New York: Routledge.

\section{BIOGRAPHICAL NOTE}

Jessica Gasiorek is an assistant professor in communication at the University of Hawai' $i$ at Manoa. Her research is on communication accommodation, social cognition, and intergroup dynamics.

Kris Van de Poel teaches Applied Linguistics at the University of Antwerp and is extraordinary professor at North-West University (Potchefstroom). She specialises in curriculum and syllabus design and coordinates the Medics on the Move project.

Together with Eddy Vanagt and Ulrike Schrimpf, Jessica and Kris recently wrote Communication skills for foreign and mobile medical professionals (Springer, 2013).

E-mail address: kris.vandepoel@uantwerpen.be 


\section{APPENDIX 1 QUESTIONNAIRE COMMUNICATIVE NEEDS OF SA CUBAN- TRAINED MEDICAL STUDENTS}

\section{INTRODUCTION}

In order to better understand your communicative needs as a medical student, we have created a survey asking you about your experiences. The data we collect with this survey will be used to improve course materials, teaching, and support we can provide you for your work in clinics and hospitals.

\section{QUESTIONNAIRE}

\section{Open Ended}

Where [location] do you plan to go practice medicine?

What will be your primary language(s) of practice for medicine? If you do not know, write 'I do not know'.

What has been most challenging (difficult, hard) since returning to South Africa, overall?

What has been most challenging (difficult, hard) since returning to South Africa, in terms of language?

What has been most challenging (difficult, hard) since returning to South Africa, in your medical studies?

What has been most challenging (difficult, hard) since returning to South Africa, in your daily life?

What is most different about your training here, compared to Cuba?

Closed Ended [5-point Likert scale]

How would you rate the quality of medical training (medical schools) in Cuba?

O Very Poor

O Poor

O Fair

O Good

O Very Good

How would you rate the quality of medical training (medical schools) in South Africa?

O Very Poor

O Poor

O Fair

O Good

O Very Good

Compared to South Africa, the medical training you received in Cuba was:

Not as good

O Equivalent

O Better 
When talking with other medical students who trained with you in Cuba, how often do you speak:

$\begin{array}{llllll} & \text { Not at all } & \text { Occasionally } & \text { Sometimes } & \text { Often } & \text { Always } \\ \text { Spanish } & 0 & 0 & 0 & 0 & 0 \\ \text { English } & 0 & 0 & 0 & 0 & 0 \\ \text { Afrikaans } & 0 & 0 & 0 & 0 & 0 \\ \text { isiXhosa } & 0 & 0 & 0 & 0 & 0 \\ \text { isiZulu } & 0 & 0 & 0 & 0 & 0 \\ \text { Another } & 0 & 0 & 0 & 0 & 0\end{array}$

When talking with other medical students who have done all their training in South Africa, how often you speak:

$\begin{array}{llllll} & \text { Not at all } & \text { Occasionally } & \text { Sometimes } & \text { Often } & \text { Always } \\ \text { Spanish } & 0 & 0 & 0 & 0 & 0 \\ \text { English } & 0 & 0 & 0 & 0 & 0 \\ \text { Afrikaans } & 0 & 0 & 0 & 0 & 0 \\ \text { isiXhosa } & 0 & 0 & 0 & 0 & 0 \\ \text { isiZulu } & 0 & 0 & 0 & 0 & 0 \\ \text { Another } & 0 & 0 & 0 & 0 & 0\end{array}$

When talking with your supervisors in hospital in South Africa, how often do you speak:

$\begin{array}{llllll} & \text { Not at all } & \text { Occasionally } & \text { Sometimes } & \text { Often } & \text { Alvay } \\ \text { Spanish } & 0 & 0 & 0 & 0 & 0 \\ \text { English } & 0 & 0 & 0 & 0 & 0 \\ \text { Afrikaans } & 0 & 0 & 0 & 0 & 0 \\ \text { isiXhosa } & 0 & 0 & 0 & 0 & 0 \\ \text { isiZulu } & 0 & 0 & 0 & 0 & 0 \\ \text { Another } & 0 & 0 & 0 & 0 & 0 \\ \text { language } & & & & & \end{array}$


When talking with your other medical students who trained with you in Cuba, how confident do you feel speaking:

Not at all

Spanish

English

Afrikaans

isiXhosa

isiZulu

Another

language
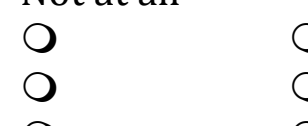

O

O

$\mathrm{O}$

○

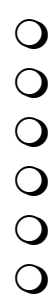

0
0
0
0
0
Very

O

$\mathrm{O}$

O

$\mathrm{O}$

$\mathrm{O}$

$\mathrm{O}$

When talking with other medical students who have done all their training in South Africa, how confident do you feel speaking:

$\begin{array}{llllll} & \text { Not at all } & & & \text { Always } \\ \text { Spanish } & 0 & 0 & 0 & 0 & 0 \\ \text { English } & 0 & 0 & 0 & 0 & 0 \\ \text { Afrikaans } & 0 & 0 & 0 & 0 & 0 \\ \text { isiXhosa } & 0 & 0 & 0 & 0 & 0 \\ \text { isiZulu } & 0 & 0 & 0 & 0 & 0 \\ \text { Another } & 0 & 0 & 0 & 0 & 0\end{array}$

language

When talking with your supervisors in the hospital in South Africa, how confident do you feel speaking:

$\begin{array}{llllll} & \text { Not at all } & & & \text { Very } \\ \text { Spanish } & 0 & 0 & 0 & 0 & 0 \\ \text { English } & 0 & 0 & 0 & 0 & 0 \\ \text { Afrikaans } & 0 & 0 & 0 & 0 & 0 \\ \text { isiXhosa } & 0 & 0 & 0 & 0 & 0 \\ \text { isiZulu } & 0 & 0 & 0 & 0 & 0 \\ \text { Another } & 0 & 0 & 0 & 0 & 0\end{array}$

When talking with a patient about medical topics, how confident would you feel speaking:

$\begin{array}{llllll} & \text { Not at all } & & & \text { Very } \\ \text { Spanish } & 0 & 0 & 0 & 0 & 0 \\ \text { English } & 0 & 0 & 0 & 0 & 0 \\ \text { Afrikaans } & 0 & 0 & 0 & 0 & 0 \\ \text { isiXhosa } & 0 & 0 & 0 & 0 & 0 \\ \text { isiZulu } & 0 & 0 & 0 & 0 & 0 \\ \text { Another } & 0 & 0 & 0 & 0 & 0\end{array}$

language 
How confident would you feel having a friendly conversation in:

language

If you could receive extra language training in one or more languages, which languages would you like to be trained in?
$\square$ English
$\square$ Afrikaans
$\square$ isiXhosa
$\square$ isiZulu
$\square$ Other (please specify)

In what areas or topics would you like extra training?

Do people here help you improve your English?

Yes

O No

If yes, please give one example how people here help you improve your English.

Do people here help you improve your Afrikaans?

O Yes

O No

If yes, please give one example how people here help you improve your Afrikaans. 
Each circle represents a group of people. Choose the pair of circles that best represents the relationship between these two groups:

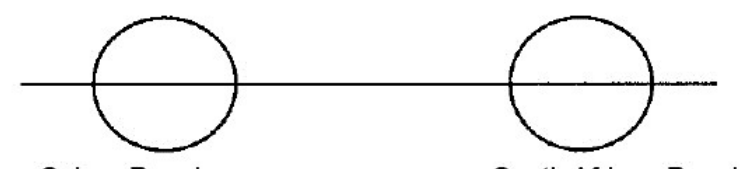

Cuban People

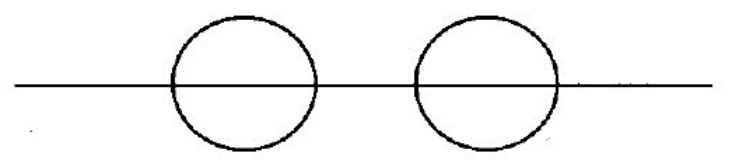

Cuban People

South African People
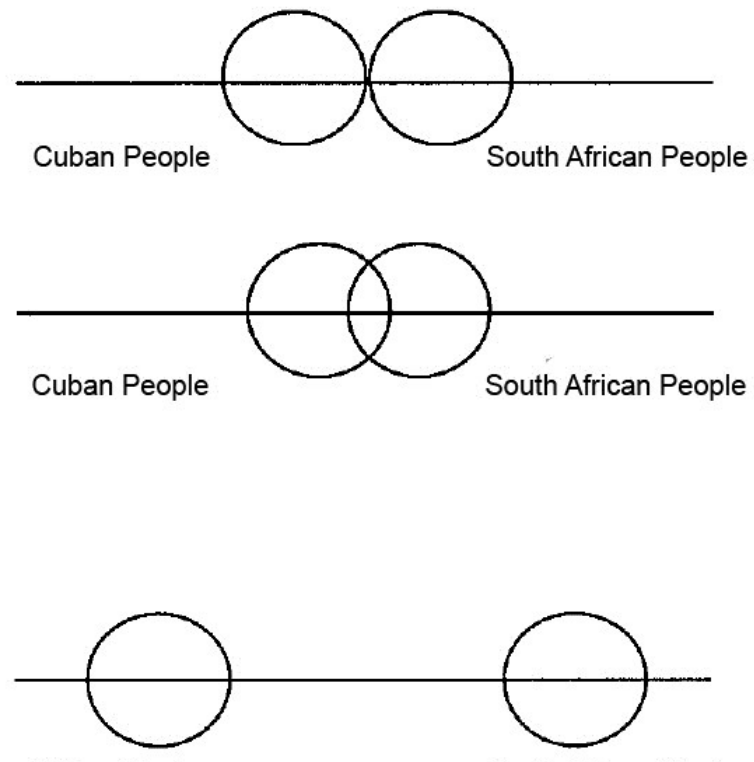

Cuban Doctors

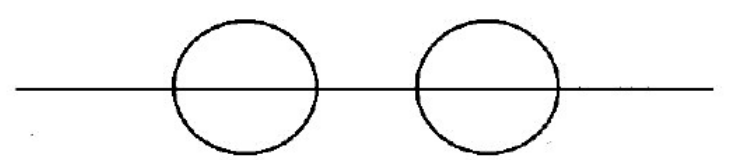

Cuban Doctors

South African Doctors
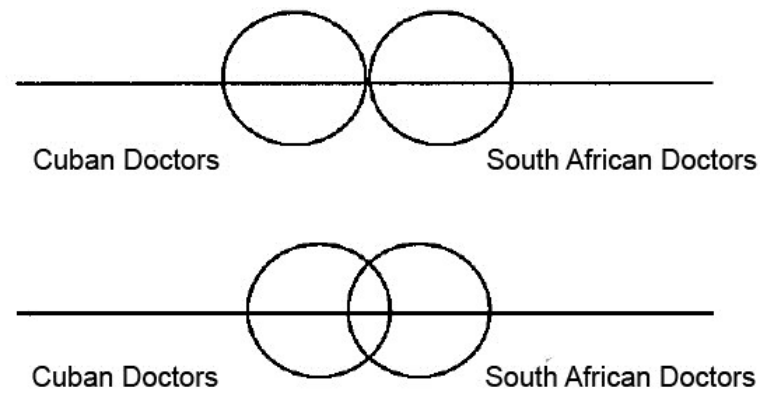
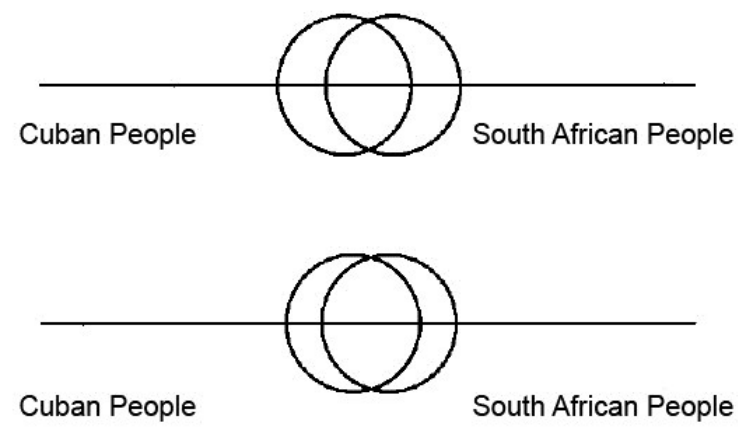

Cuban People

South African People
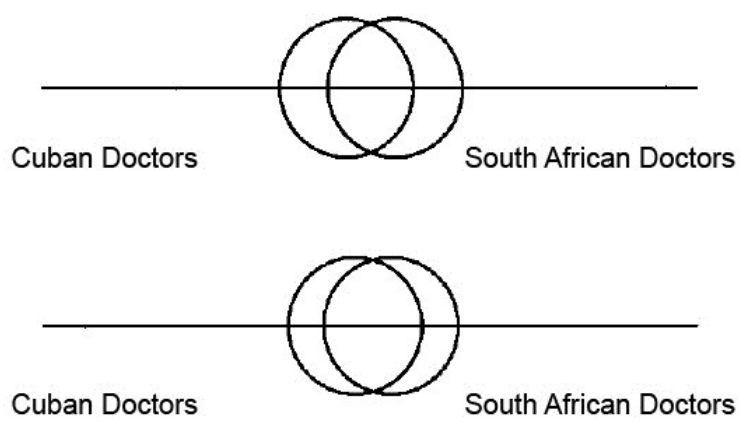

Cuban Doctors

South African Doctors 


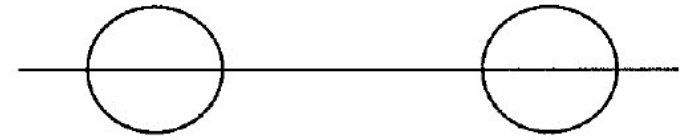

Doctors Trained in Cuba Doctors Trained in South Africa

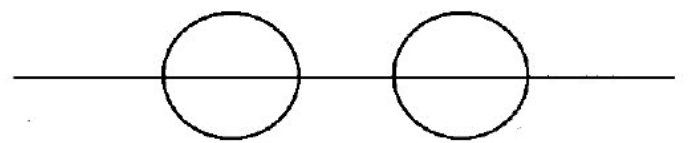

Doctors Trained in Cuba

Doctors Trained in South Africa

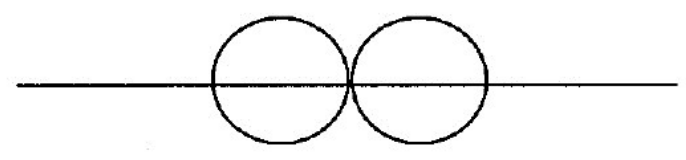

Doctors Trained in Cuba

Doctors Trained in South Africa

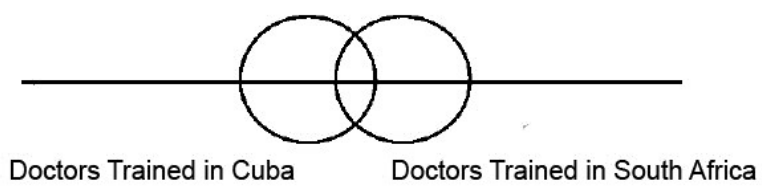

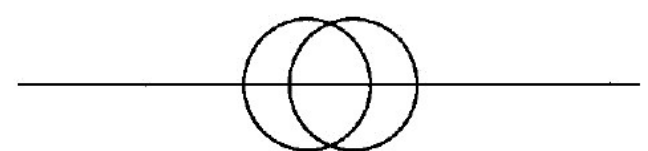

Doctors Trained in Cuba

Doctors Trained in South Africa

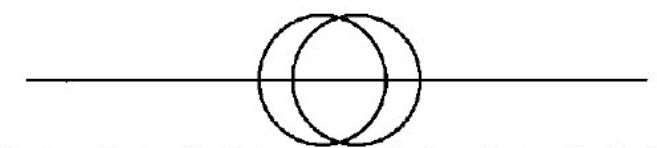

Doctors Trained in Cuba

Doctors Trained in South Africa

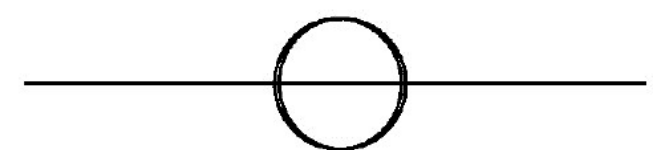

Doctors Trained in Cuba

The small circle represents you. The big circle represents a group of people. Choose the pair of circles that best represents the relationship between you and this group of people.
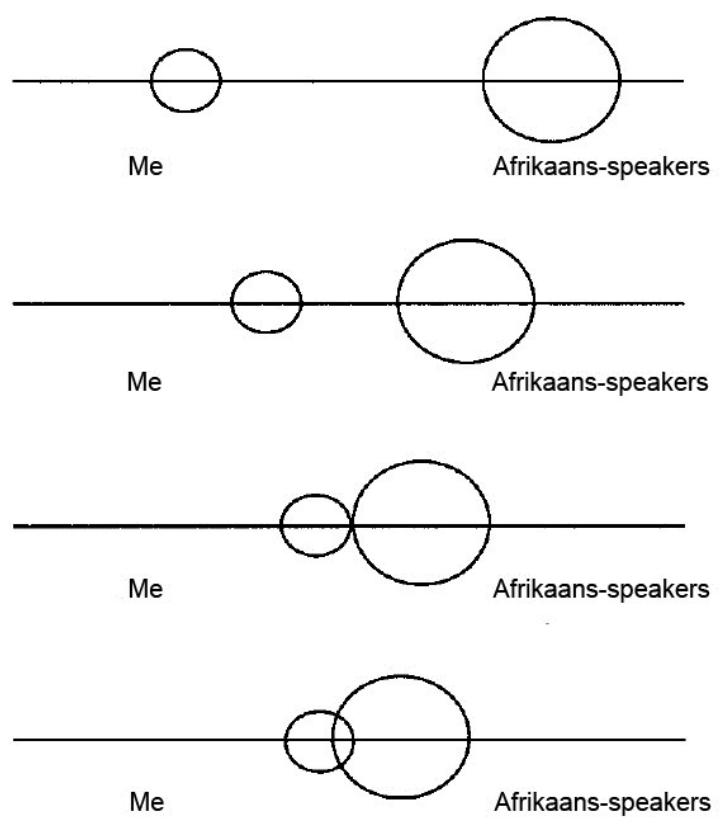
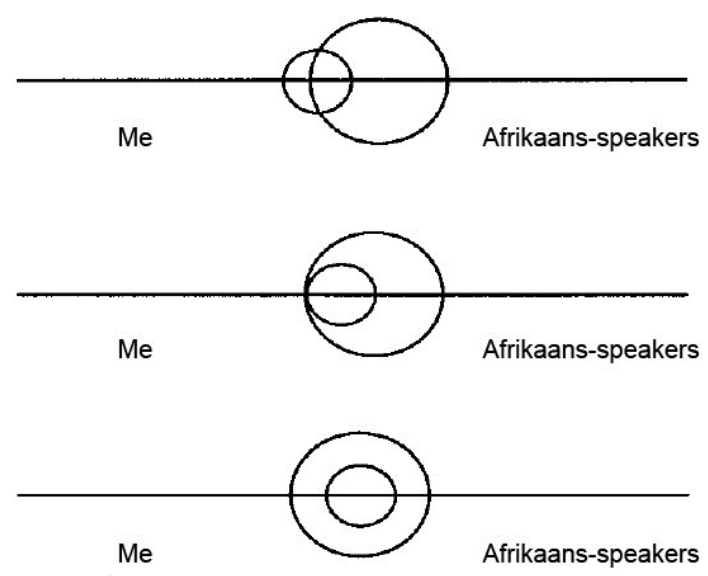

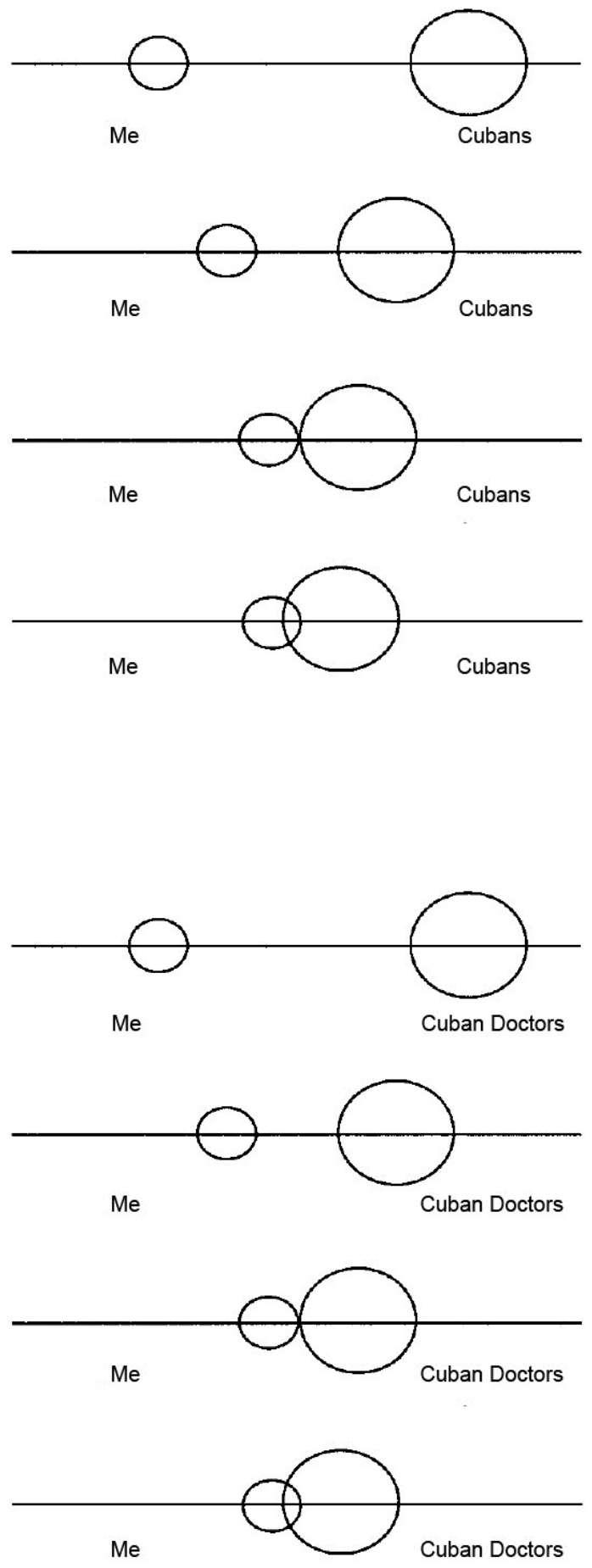
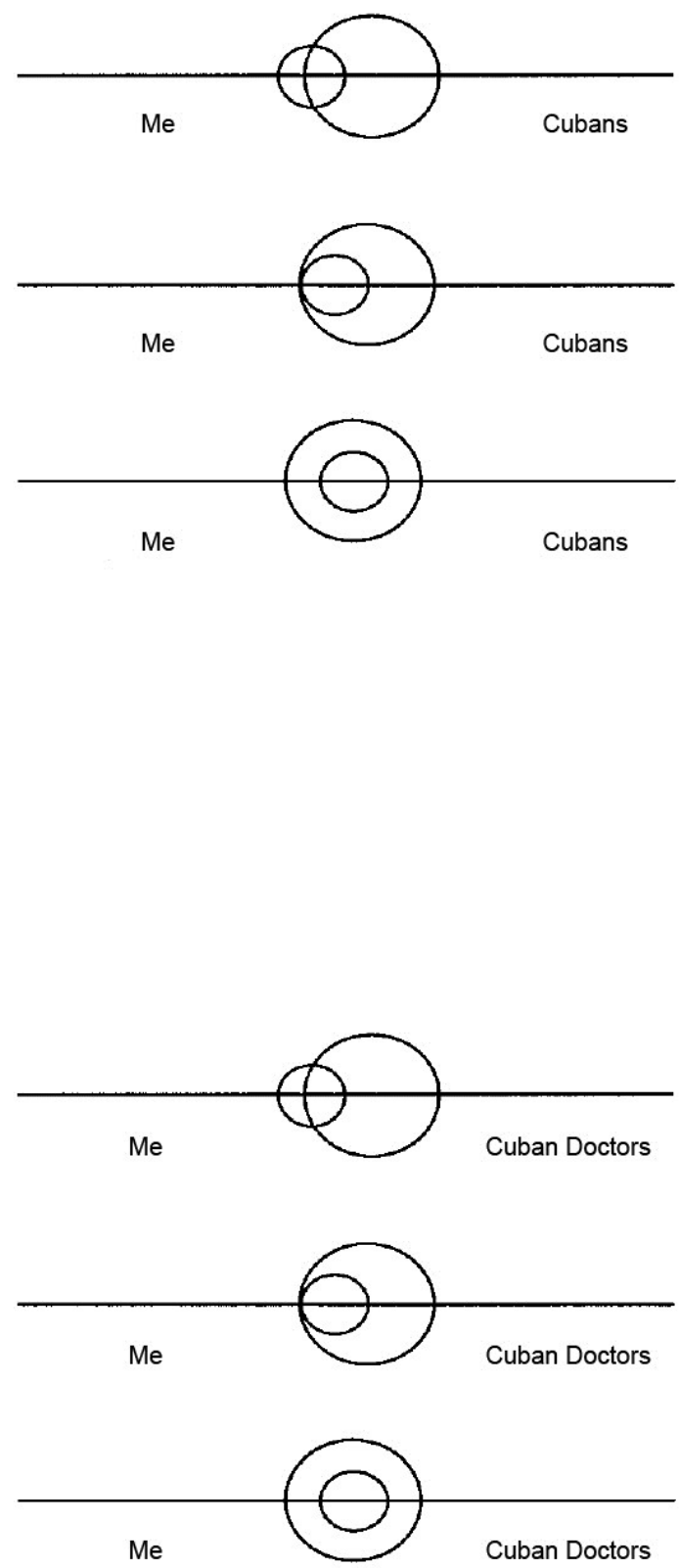

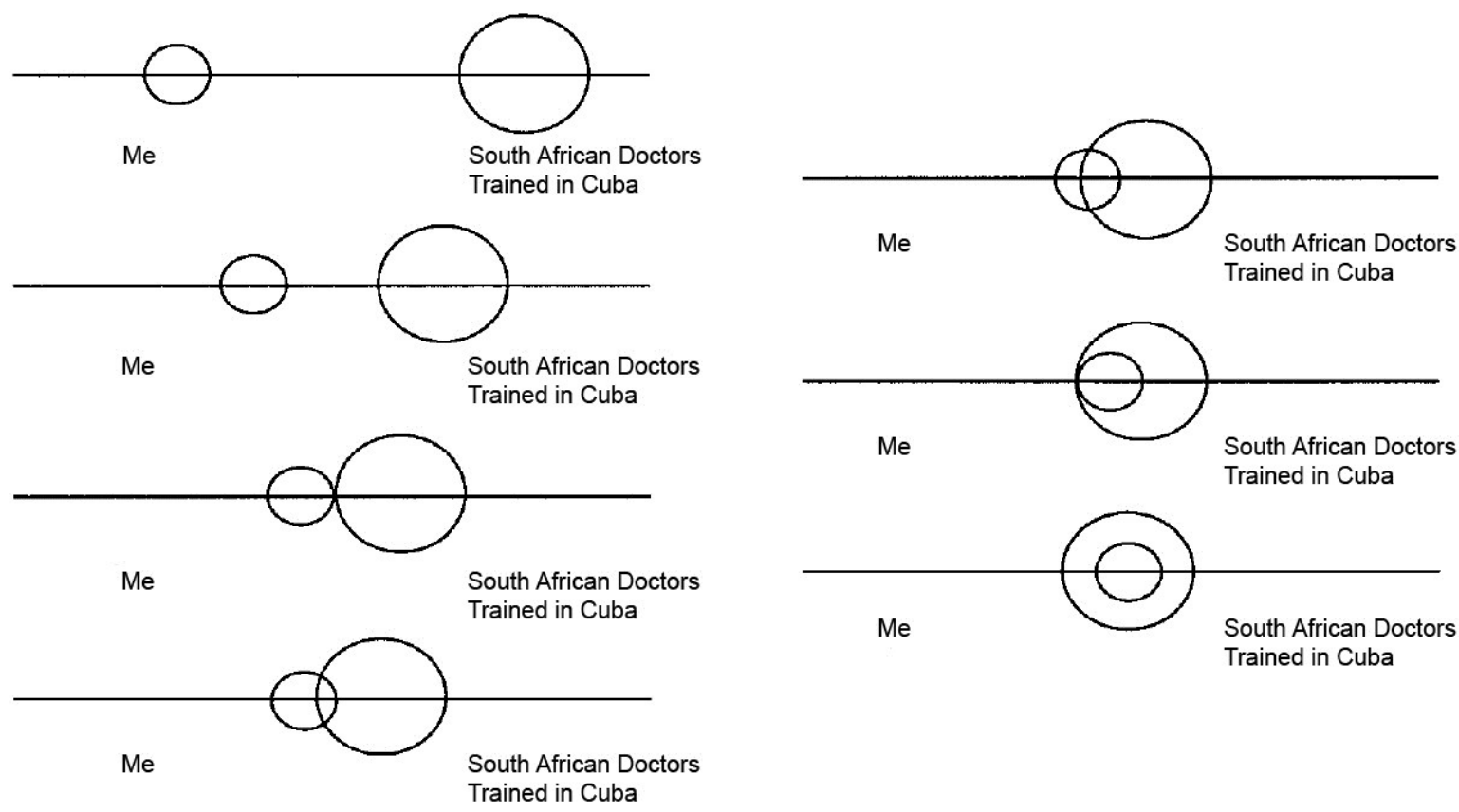

Trained in Cuba

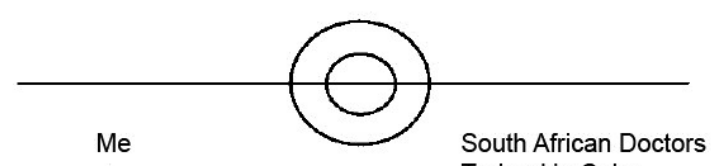

Trained in Cuba
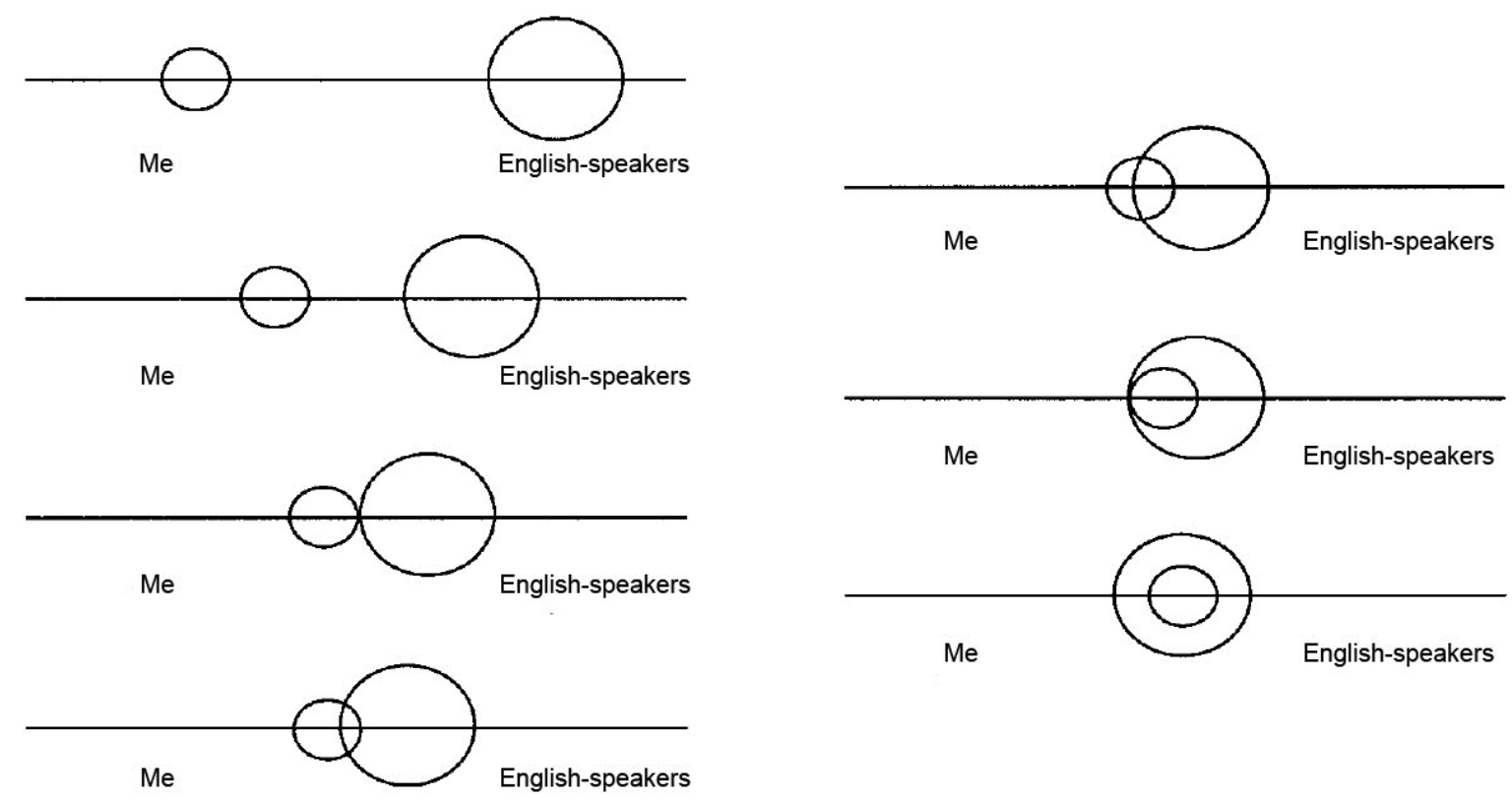

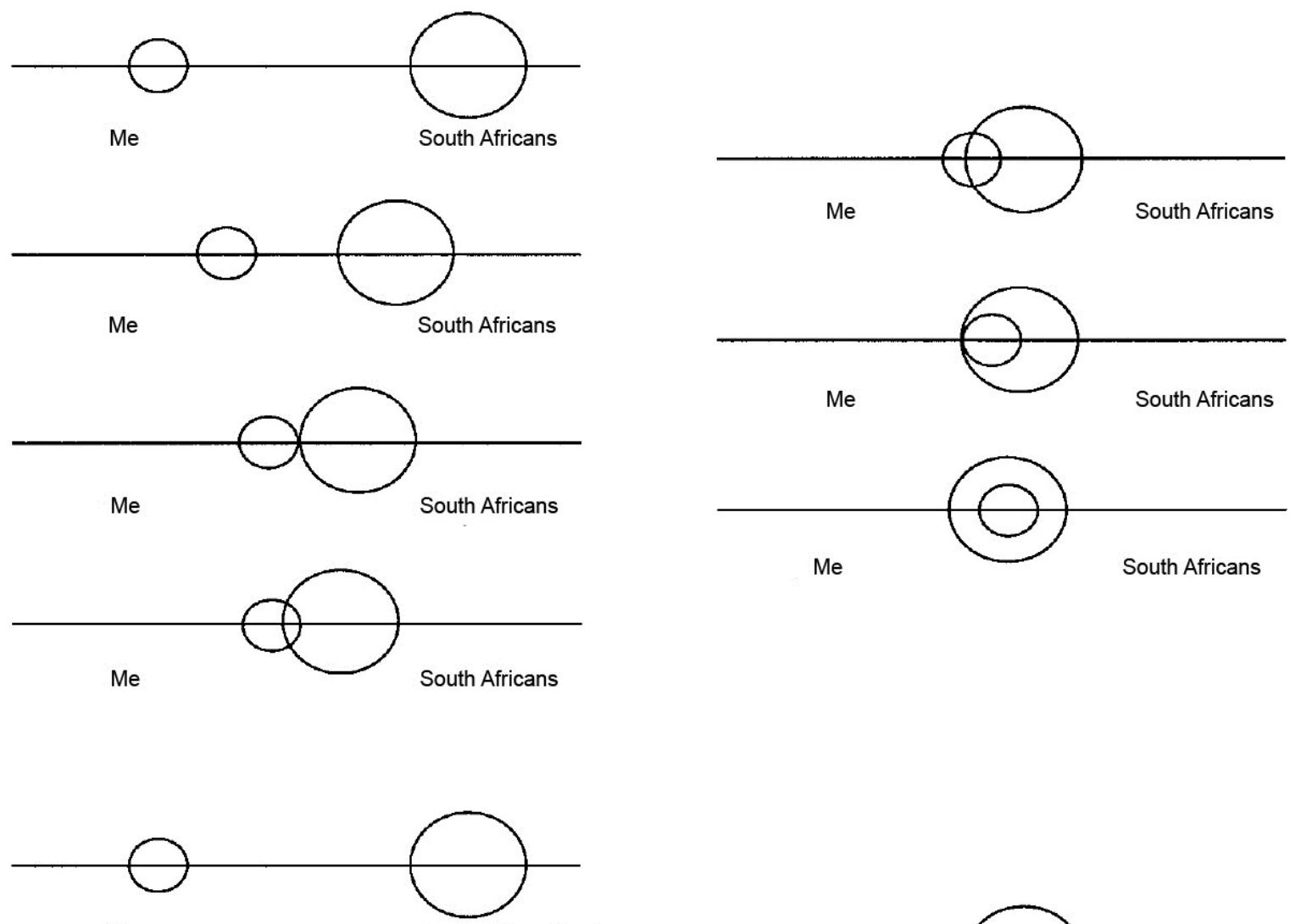

$\mathrm{Me}$

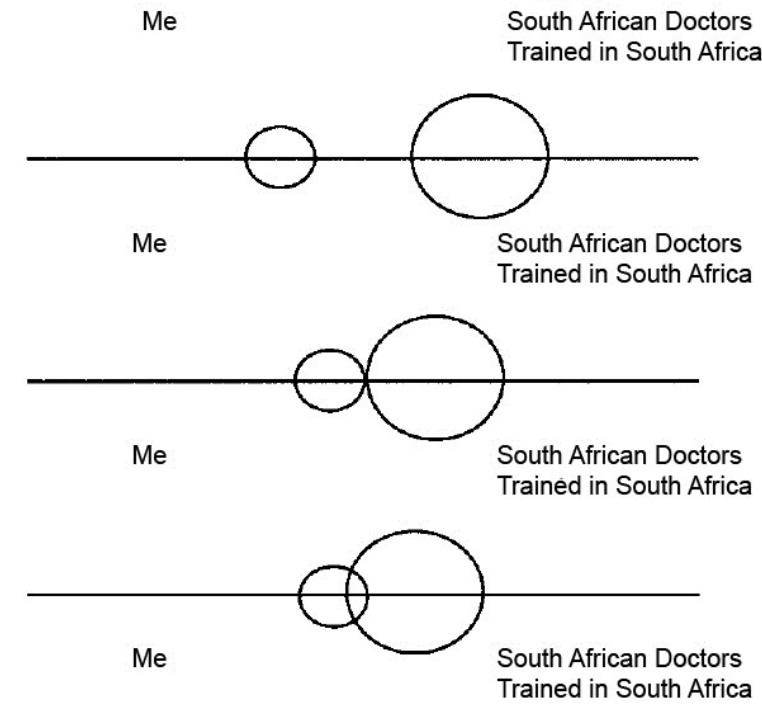

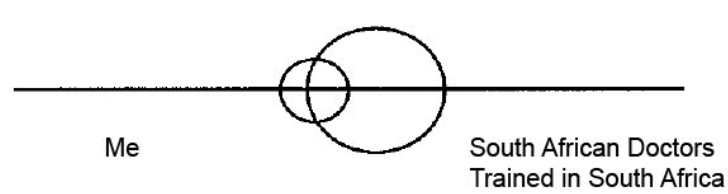

Me South African Doctors

Trained in South Africa

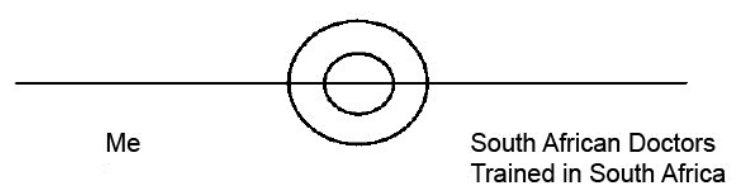



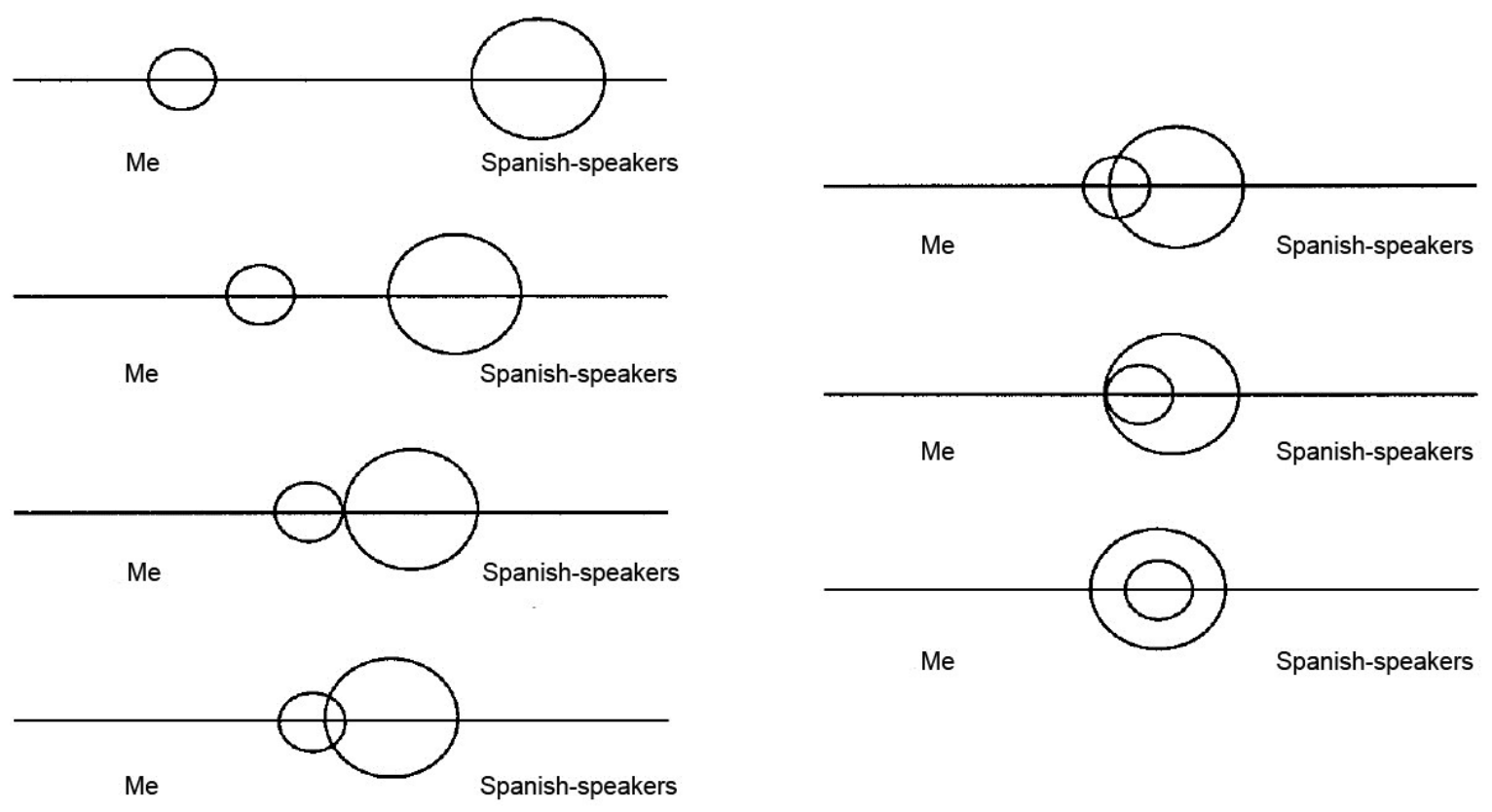

\section{Demographics}

What is your age (in years)?

What is your sex?

O Male

O Female

What is your ethnicity?

What languages do you speak?

How many years of medical training have you completed?
○ 1
○ 2
○ 3
○ 4
○ 5
O 6
○ 7

Where did you receive the first part of your medical training?

O Cuba

O South Africa

Other (please specify)

How long were you in Cuba?

O 1 year

O 2 years 
J Gasiorek \& K van de Poel

$\begin{array}{ll} & 3 \text { years } \\ 0 & 4 \text { years } \\ \bigcirc & 5 \text { years } \\ 0 & 6 \text { years }\end{array}$

How long has it been since you returned to South Africa? 